\title{
Javanese Language Maintenance Based on Sociocultural Approach (A Case Study on Women in Rembang, Central Java)
}

\author{
Suharyo*, Nurhayati \\ Faculty of Humanities, Universitas Diponegoro, Semarang
}

\begin{abstract}
Like other regional languages in Indonesia, Javanese language is progressively endangered by Indonesian language. This research employs a questionnaire and observation to answer the given hypothesis. The results indicate that , (a) the Javanese language variety of "ngoko" is still moderately maintained by the speakers (women in Rembang coastal area), (b) the Javanese krama variety is almost extinct, (c) Indonesian and mixed languages have threatened the existence of Javanese. Several efforts made to preserve Javanese language is by exerting sociocultural approach, namely (a) speaking in Javanese language at home, (b) speaking in Javanese language with neighbors, (c) formal education, (d) non-formal education, (e) art / tradition, (f) religious activities, and (g) media.
\end{abstract}

Keywords: language maintenance, Javanese language, sociocultural approach

\section{Introduction}

Language is an inseparable part of culture which is considered to be important and to have strategic standing. This is due to the reason that language creates human existence to be more prestigious. Besides, language becomes "the silent witness" of culture and civilization of society and nation. For instance, we know 7 wonders of the world by means of language, humans even were created because of the use of language (qun fayakun, Be, and it is). What about culture? Culture can be defined as a norm or blueprint that is employed as a life guidance in society consisting of ideas, doings, and creations. Culture can be seen in cognitive and behavioristic paradigms. In cognitive paradigm, culture is viewed as a set of (abstract) thoughts, such as values, ideas, norms, etc; meanwhile culture in behavioristic paradigm is determined as an embodiment of human pattern doings (behaviors) that can be concretely observed Sibarani [4] Therefore, language can possibly be regarded in terms of cognitive and behavioristic perspectives inasmuch as language is a set of ideas occurring on social cognition. However, when the given language is used as a tool in social interaction,

\footnotetext{
${ }^{*}$ Corresponding author : haryo.sastra@gmail.com
} 
it is a pattern of behaviors. Saussure, in this context, employed the terms "langange", consisting of two concepts langue (abstract) and parole (concrete), whereas Chomsky mentioned deep structure and surface structure. Another familiar concept is the notion of linguistic competence and linguistic performance.

Referring those explanations, language maintenance in this research denotes a set of ideas (cognitive culture) and language use by society (behavioristic culture). Thus, Javanese language maintenance embodies a set of ideas lying on collective cognition of people in Rembang, for instance the Javanese language system (ngoko, krama, and its varieties; its standard use, etc); and the term "maintenance" implies a social phenomenon of language use in Rembang used by people as a tool to interact with each other. It is said as a communication tool because people in Rembang apparently are able to use other languages, for example Indonesian language, and even Arabic language.

When they use either a certain language or a certain variety, they practically deal with several language or variety choices which they know it is not easy to choose because they are commonly bilingual even multilingual. Thereupon, there are some obstacles for them to opt Javanese ngoko (rough/refined), krama (madya, inggil), Indonesian language or other languages. Those problems are for example to whom, when, where, how they are talking, etc. This leads to the language/variety choices becoming "a battle arena" to speakers in Rembang. A battle surely has the winner, the loser, or the survivor. The term "Javanese language maintenance" contextually appears in this research taken from the concept of "battle".

Language shift and language maintenance in several studies are considered as two sides of the same coin. Another term that resembles this phenomenon is a double edged sword. One language or variety is chosen, and one is maintained. Agus Wijayanto (2007) mentioned that Javanese language has lost its speakers especially young speakers. This accords with Suharyo's research (2017:2018) indicating that young Javanese speakers will quit conversing in Javanese/their regional language. Meanwhile, Saddhono and Rohmadi (2014) emphasized the use of Javanese language in education mainly first grade up to third grade of elementary school. Thus, promoting education based on mother language is crucial (Sugiharto, 2014) so regional languages do not extinct and are able to preserve its existence. The research conducted by Saddhono and Rohmadi was supported by Maria Botivar (2015) who said that curriculum of language should be established on the basis of the learners' needs that is multicultural, so people are involved actively and massively to maintain mother language. This is done to take into account that regional language/mother language becomes endangered. Besides, Botivar urged (1) government to be assertive, (2) school to take over jobs and roles of family in terms of regional language/mother language maintenance. On the other hand, Nurhayati et. A. (2013) proposed 6 strategies in maintaining language. Those plans include (1) the Javanese language use as a communication tool in family, (2) the use of Javanese language with cultural context in some events (sea thanksgiving, earth thanksgiving, etc), (3) using Javanese language in local culture (traditional Javanese song competition, egrang, gobag sodor, etc) (4) the roles of regional government, (5) the roles of non-governmental organizations and art center, and (6) promoting language, literature and culture broadcasting by mass media and electronic media. The question are how are Javanese language maintenances in Rembang? and How are the Rembang people's roles in maintaining Javanese language? This study aims to discover the answer. 


\section{Result and Discussion}

\subsection{Result}

The results show that the sixty percent $(60 \%)$ of women living in Rembang waterfront area speak in ngoko, but Indonesian language begins to threat with twelve percent of people speaking in it, and another threat is mixed-language with eight percent $(8 \%)$ of speakers. The percentage of the mixed-language use is based on the observation of people aged under 35 who prone to shift their language to Indonesian due to their wide social level and high mobility. Meanwhile, krama Javanese language is stuck in $1 \%$. This means that krama is predicted to be extinct soon.

Furthermore, the results of women living in Rembang rural area indicate that forty eight percent $(8 \%)$ of them maintain to speak in ngoko (lesser than Rembang waterfront area), twenty percent $(20 \%)$ speak in Indonesian, the mixed-language was spoken by seven percent $(7 \%)$, and another eleven percent speak in krama. According to those results, Indonesian language spoken women in rural area is more jeopardizing the existence of Javanese language than that spoken by women in waterfront area. Mixed-language percentage of women in rural area are likewise higher than that of women in waterfront area. However, krama, the variety of Javanese language spoken by women in Rembang rural area is higher than that spoken by women in Rembang waterfront area.

Javanese language maintenance. Javanese language, mainly ngoko, maintenance on Rembang people especially women, is well-maintained on social institutions such as, family, neighborhood, social activities (arisan, dawis, Integrated Service Post). Krama is only maintained in family scope and seldom in matrimonial ceremony. Meanwhile, mixedlanguage is spoken almost in every social institutions, for instance: home/family, neighbourhood, friendship, social activities (arisan, dawis, Integrated Service Post, religious activities, etc)

Javanese language maintenance based on sociocultural approach. The efforts to maintain Javanese language conducted by women in waterfront area are (a) using Javanese language when talking to family members (b) speaking in Javanese language to relatives or neigbours, (c) involving the use of Javanese language in social activities such as social gathering/arisan, Integrated Service Post, dawis; (d) exerting Javanese language in religious institutions, such as tausiah, routine Qur'an recitation; (e) using Javanese language in formal education, especially in the first up to third grade of elementary school, (f) applying the use of Javanese language as social communication in non-formal education, for examples dance training, singing Javanese songs (g) practicing Javanese language in certain traditional events, such as sea thanksgiving.

\subsection{Discussion}

Reviewing those points, Javanese language continuously is used by women in both waterfront and rural area $(48 \%-60 \%)$. However, it should take into consideration that the well-maintained language is ngoko, while krama is in critical condition if it is not mentioned "almost extinct", likewise creole Tugu (Suratminto, et.al., 2016). The percentage of ngoko is only about $60 \%$, that is not so a pleasing number since it is Javanese languge and it is threatened by Indonesian language and mixed-language. The Javanese language will probably share the same condition with creole Tugu, if concrete and continuous efforts are not taken.

To overcome the extinction of Javanese language, several efforts that had already taken are Javanese languagse use in social institutions (a) nuclear family/home (b) neighbourhood 
(c) social activities (dawis, routine social gathering) (d) religious activities (Qur'an recitation) (e) traditional practices (sea thanksgiving) (f) formal education, (g) art (art centre). These results are aligned with the research conducted by Endang Nurhayati, et.al (2013). Besides the use of Javanese Language in those 7 social institutions, curriculum of Javanese language needs to be reinforced according to Sugiharto (2014), Saddhono dan Rohmadi (2014), dan Botivar (2015). Furthermore, government roles have to be improved and intensified as ruled in UU No.24/2009 and UUD 45, article 36.

\section{Conclusion}

There are some notes as a conclusion. First, Javanese is still well-maintained by women in Rembang waterfront area $(40 \%-60 \%)$. Second, Indonesian has been used as mother language $(7 \%-12 \%)$. Third, the women in Rembang waterfront area are in transition, as indicated by the use of mixed-languages $(8 \%-11 \%)$. Fourth, krama as one of varieties Javanese language spoken by women in Rembang rural area is higher in percentage compared to that spoken by Rembang waterfront area. Fifth, Rembang people are classified as a bilingual community even as multilingual (small percentage). Sixth, the pattern of Javanese language maintenance based on socio-cultural approach in institutions: family, neighborhood, social activities, formal education (elementary grades 1 to 3), non-formal education (dance center), traditional events (sea thanksgiving), religious institutions (Qur'an recitation groups, religious education NU ), early childhood education (ECE). Seventh, Indonesian language has threatened the existence of Javanese language. Eighth, several efforts need to be done so Javanese language is not increasingly displaced or retained by the speech community, such as (a) reinforcing the Javanese language curriculum based on the needs of learners, (b) decisive and massive roles of government, (c) education becomes the support and contributor that need to be strengthened its function and role in maintaining/preserving the regional languages in general and Javanese in particular, (d) the function and role of the media are extremely important in helping to preserve and maintain local languages (read: Javanese).

\section{References}

1. Botivar, Maria.’Pemertahanan Bahasa dan Pengembangan Kurikulum Bahasa Berbasis Analisis Kebutuhan” Prosiding Seminar Nasional Bulan Bahasa UNIB. (2015)

2. Nurhayati, Endang, et.al. "Strategi Pemertahanan Bahasa di Daaerah Istimewa Yogyakarta" dalam LITERA Vol 12, No.1 (2013)

3. Nurwahidah, Lina Siti. "Pelestarian Bahasa dan Prindip-Prinsip Budaya Lokal Berbasis Pendidikan Multikultural di Indonesia" dalam Journal of Education Exsperts, Vol.2,No.1 (2019)

4. Sibarani, Robert,2004, Antroplogi linguistic, Medan: peneerbit Moda

5. Sugiharto, Setiono. "Urgensi Mempomosikan Pendidikan Berbasis Bahasa Ibu: Sebuah Kasus di Indonesia" dalam The International Journal of Foreign Language Teaching, Vol.10, Issue 1 (2014)

6. Suharyo. "Pemilihan Kode pada Generasi Muda Non-Jawa" dalam NUSA, Vol.12, No.4 (2017) 
7. Suharyo. "Nasib Bahasa Jawa dan Bahasa Indonesia dalam Pandangan dan Sikap Bahasa Generasi Muda Jawa" dalam NUSA, Vol.13, No. 2 (2018)

8. Suratminto, Lilie et.al. Kepunahan Bahasa: Bahasa Kreol Tugu yang Punah dalam Pemertahanan Budaya Tugu. Jakarta: FIB Universitas Indonesia. (2016)

9. Wijayanto, Agus. "Pemilihan Bahasa yang Dilakukan oleh Anak-Anak Remaja Etnis Jawa di Kecamatan Kalasan, Yogyakarta, Indonesia" dalam Kajian Linguistik dan Sastra, Vol.19, No.1 (2007) 